\title{
Genomic profile of pulmonary follicular dendritic cell sarcoma: a case report and systematic review
}

\author{
Liyuan Fan ${ }^{1,2}$, Hongsheng $\mathrm{Li}^{2}$, Minghao $\mathrm{Li}^{1,2}$, Yang Zhang ${ }^{2}$, Jianping Zhang ${ }^{3}$ and \\ Baosheng $\mathbf{L i}^{2}$ \\ ${ }^{1}$ Cheeloo College of Medicine, Shandong University, Jinan, China \\ ${ }^{2}$ Department of Radiation Oncology, Shandong Cancer Hospital and Institute, Shandong Cancer Hospital Affiliated to \\ Shandong University, Jinan, China \\ ${ }^{3}$ Department of Pathology, Qilu Hospital, Shandong University, Jinan, China \\ Correspondence to: Baosheng Li, email: baoshli1963@163.com
}

Keywords: pulmonary FDCS; copy number variants; high-throughput sequencing; tumor genomic profiling; REL

Received: June 22, $2017 \quad$ Accepted: December 28, $2017 \quad$ Published: January 02, 2018

Copyright: Fan et al. This is an open-access article distributed under the terms of the Creative Commons Attribution License 3.0 (CC BY 3.0), which permits unrestricted use, distribution, and reproduction in any medium, provided the original author and source are credited.

\section{ABSTRACT}

Follicular dendritic cell sarcoma (FDCS) is an extremely rare neoplasm which involves both nodal and extranodal sites. The demographics, pathological characteristics and clinical features of this tumor have been reported a lot, but the genomic information is still insufficient.

Here we presented the ninth case of pulmonary FDCS in English publication, whose diagnosis has been revised from "synovial sarcoma" to FDCS. The patient underwent a right pneumonectomy and died of sudden cardiac death within a week after the surgery. Because of the lack of genomic characterization of the tumor, we used the OncoScan ${ }^{\circledR}$ gene chip, which has been optimized for detection of whole genome CNVs. By bioinformatics' analysis and thoroughly literature review, we found the following suspicious functional genes REL, TET2, CREBBP and CYLD. These genes we found may have important influence on the fate of the neoplasm. Further study for their role of diagnostic and therapeutic targets is needed.

\section{INTRODUCTION}

FDCs are fundamental constituent members of primary and secondary lymphoid follicles, which are located mainly in the lymph nodes, as well as extranodal sites [1]. Hyperplasia of FDCs occurs in a number of reactive and neoplastic conditions and the first characterized FDCS was depicted by Monda et al in 1986 [2]. In the 2008 WHO Classification of Tumors of Hematopoietic and Lymphoid Tissue [3], FDCS belongs to a separate category of histiocytic and dendritic cell neoplasms, among which histiocytic sarcoma, Langerhans cell histiocytosis, Langerhans cell sarcoma, interdigitating dendritic cell sarcoma, and disseminated juvenile xanthogranuloma were also included. A definitive diagnosis may be obtained with pathological analysis and identification of positivity for CD21 and
CD35 by immunohistochemical examination [4], but the misdiagnosis is still easy to be made. No global landscape of CNVs has been identified for this tumor yet. Here, we present a case of FDCS and its genetic characteristics on OncoScan ${ }^{\circledR g}$ gene kit test in a Chinese female and review the relevant literature.

\section{CASE PRESENTATION}

During a routine evaluation, the chest X-ray of a 44-year-old woman showed an asymptomatic right pulmonary hilar mass. The follow-up computed tomographic (CT) scan of the chest documented the presence of a $7.5 \mathrm{~cm} \times 7.0 \mathrm{~cm}$ mass. The contrast enhanced chest CT showed that a mass existed in the right pulmonary hilar region, which was well-circumscribed without predominant lobulated and spiculated sign, was 
slightly heterogeneous without calcification and was connected with the paravertebral pleura. It also showed enlarged lymph nodes in the pulmonary hilar and mediastinal region, including level 10, level 11, level 7 and level 4R, the largest of which was $1.8 \mathrm{~cm}$ in diameter. All other physical and routine laboratory examination results were negative.

A CT-guided biopsy of the mass was performed and "mesenchymal tissue malignant tumors" was rendered. The remote consultation of pathology suspected "spindle cell cancer" and the immunohistochemistry (IHC) supported "synovial sarcoma". Another CT-guided biopsy was conducted and the diagnosis was revised to FDCS. Following the initial evaluation, the patient underwent a right pneumonectomy (Figure 1).

Postoperative macroscopic pathology revealed that a $13 \times 12 \times 10 \mathrm{~cm}^{3}$ mass surrounded the right pulmonary trunk and pointed front-end branching roots, as well as infiltrated the intermediate bronchus, the root of superior lobar bronchus and visceral pleura. Microscopically, the neoplasm was highly cellular and arranged primarily in short, compact, intersecting storiform or whorling patterns (Figure 2A). The neoplastic cells were spindled to ovoid shape, with indistinct cell border and with light to abundant eosinophilic cytoplasm. The tumor cell nuclei were round to vesicular, with delicate membranes and a typical small central nucleoli, and intranuclear inclusions were found occasionally (Figure 2A, a). Mitotic figures were 1 2 per 10 high power fields (HPF) and necrosis was suspected in some areas. Focal metastasis was found in the evaluated 37 peribronchial, mediastinal and hilar lymph nodes (Figure 2B). IHC demonstrated that the tumor cells were positive for CD21 (Figure 2C), CD35 (Figure 2D), fli-1, vimentin and D2-40 (Figure 2E). The cells were also suspiciously positive for CD99 and Bcl-2. The tumor cells failed to express CD3, CD17, CD20, CD23, CD30, CD31, CD34, CD45, CD56, CD68, CD1 $\alpha$, CK 8/18, CKPan, DOG-1, Desmin, EMA, GFAP, Pax-5, mum-1, SMA, S-100, Syn, and ALK/P(80). The ki-67 index was about $30 \%$ (Figure $2 \mathrm{~F}$ ). EBER was not identified in the tumor cells. Unfortunately, the patient died of sudden cardiac death within a week after the surgery (Figure 1).

To further reveal the genomic characteristics of this rare neoplasm, a MIP chip array of OncoScan ${ }^{\circledR}$ Assay Kit was used with paraffin-embedded (FFPE) samples. The raw data were analyzed and visualized by illumia' offical software OncoScan Console and BioDiscovery's Nexus Express. CNVs and the ploidy were mainly inferred by the segment distribution of probe $\log _{2}$ ratios and $\mathrm{B}$-allele frequencies (BAFs). We found that no $\mathrm{SN}$ variants were detected while the chip includes 900 cancer genes. The $\mathrm{CN}$ analysis showed a $41.58 \%$ genomic change which mainly presented as copy loss. In chr2, chr3, chr5, chr6, chr9, chr10, chr13, chr14, chr16, chr22 and chrX, loss of large segmentation and LOH were observed (Figure 3). The involved oncogenes tracking from Cancer Gene Census were collected and explored one by one. We paid more attention to genes with exceptional CNVs comparing to the adjacent parts. Finally, by combining TCGA and literature review, we focused on the genes closely

\section{A Diagnosis and treatment}

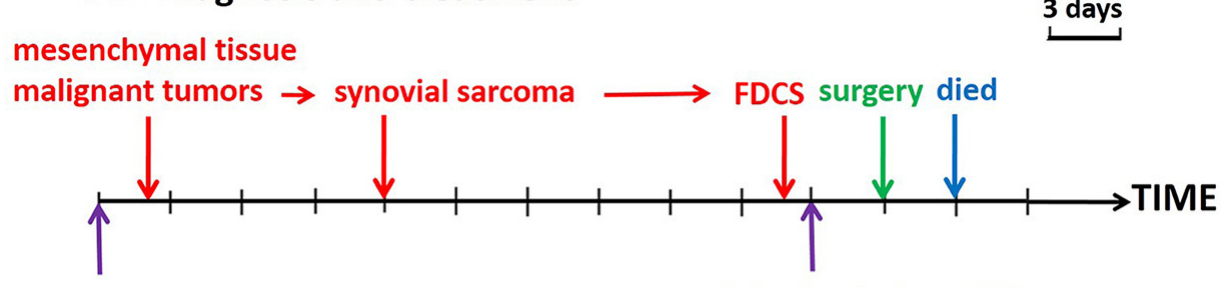

a.Patient's chest CT

b.Patient's chest MRI
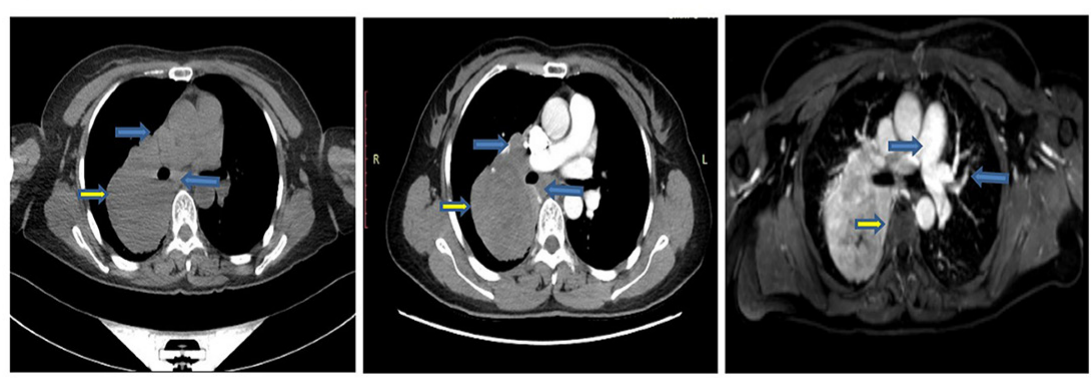

\section{B Image examination}

Figure 1: Summary of monitoring and treating the patient over time. (A) Red arrowheads indicates time points for different diagnoses that the pathologists made. Green arrowhead indicates time point for the treatment. Blue arrowhead indicates time point for the ending of the patient. (B) Purplearrowheads indicate time points of chest CT image and chest MRI image before treatment. Yellow arrowheads showed a mass in the right pulmonary hilar region and blue arrowheads showed enlarged lymph nodes. 
associated to tumors of hematopoietic and lymphoid tissue, and the following genes REL (Figure 4A), TET2 (Figure 4B), CREBBP (Figure 4C) and CYLD (Figure 4D) were targeted for further discussion.

\section{DISCUSSION}

Here we report a rare neoplasm, which is the ninth case of primary pulmonary FDCS in English publication [5-11] (Table 1). In our case, the initial speculation was synovial sarcoma, which is composed of epithelial or spindle cells and is positive for EMA, CK, BCL-2, vimentin etc [12]. The intersecting storiform, existence of epithelioid cells and suspicious positive for CD99 and BCL2 confused the pathologist, but the negative expression for CD21 and CD35 helped us make exclusive diagnosis. Other confusable tumors include interdigitating dendritic cell sarcoma (IDCS), ectopic meningioma, ectopic thymoma, malignant fibrous histiocytoma, inflammatory pseudotumor, malignant peripheral nerve sheath tumor, angiosarcoma or hemangioendothelioma, lymphoepithelioma-like sarcoma, malignant melanoma, gastrointestinal stromal tumor and soft tissue sarcoma
[13]. The rareness of this disease and the lack of specific clinical and imaging features make it easy to misdiagnose, but it is just the first reason. The second is that the key to differential diagnosis is IHC. However, it needs a high index of suspicion and can be achieved only conditionally. If the pivotal targets were not tested, the misdiagnosis would be made. Then we explored the genomic characteristics of this tumor, which may be helpful to make diagnosis, just like the $B C R-A B L 1$ for Chronic myelogenous leukaemia and PDGFRA, PDGFRB or FGFR1 for myeloid and lymphoid neoplasms [3].

The largest pooled analysis was performed in 2013 by Saygin et al. [14], which illustrated demographics, pathological characteristics and clinical features of patients with this rare tumor. However, no genetic abnormalities have been identified as defining this tumor. Some efforts have been made in this respect. Perry AM et al. [15] summarized the cytogenetic findings on FDCS but confirmed no consistent or specific aberration. Starr JS et al. [16] first characterized DNA mutations in this disease and found three gene mutations: PTEN, RET and TP53. Heounjeong Go et al. [17] found that FDCS exhibited a $18.5 \%$ (5 in 27 cases) rate of $B R A F^{V 600 E}$
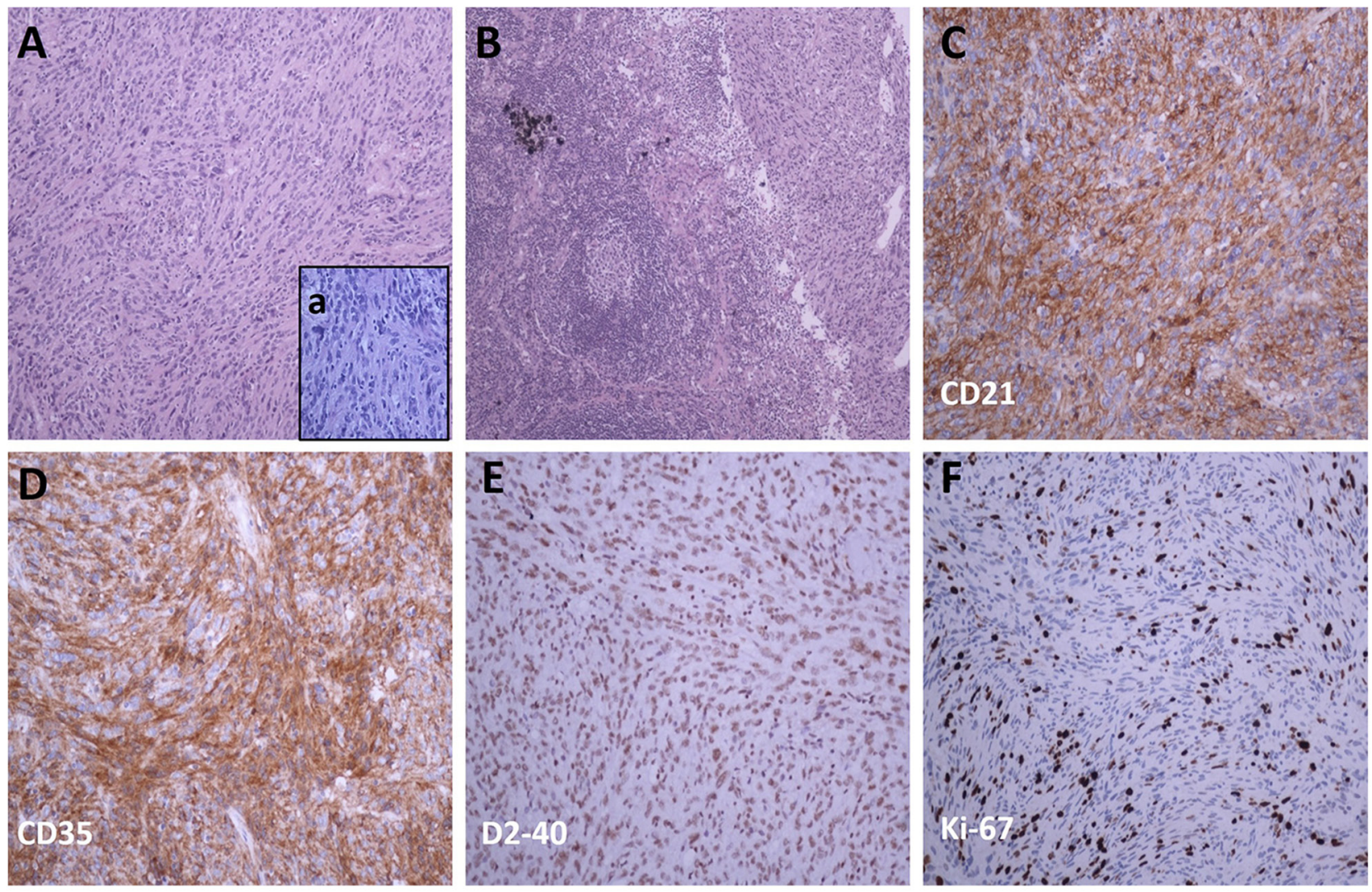

Figure 2: Histomorphological details and diagnostic immunomarkers of FDCS. (A) The neoplasm was highly cellular and arranged primarily in short, compact, intersecting sheet-like storiform or whorling patterns (H\&E staining; Magnification, $\times 10)$. (a) The neoplastic cells were spindled to ovoid shape, with indistinct cell borders and with a light to abundant eosinophilic cytoplasm (H\&E staining; Magnification, $\times 20$ ). (B) The metastasized tumor tissue in lymph node (H\&E staining; Magnification, $\times 10)$. (C-E) CD21, CD35, D2-40 expression were diffusely positive in the tumor cells. (F) The ki-67 index is about $30 \%$ (IHC staining; Magnification, $\times 20$ ). 
mutation, which hints that $B R A F$ pathway may make a contribute to the pathogenesis of this disease. Sylvia Hartmann et al. [18] divided FDCS into two subgroups by high and low miRNA expression levels while they did no difference on BRAF mutation status. By targeted genomic sequencing of FDCS, Gabriel K Griffin et al. [19] revealed recurrent loss-of-function alterations of $N F K B I A$, $C Y L D, C D K N 2 A$ and $R B 1$, which were involved in $N F-\kappa B$ regulatory pathway (5 of 13 cases, $38 \%$ ) and cell cycle progression (4 of 13 cases, 31\%). Moreover, they also found focal copy number gain of chromosome 9p24 (3 of
13 cases, $23 \%$ ) that contains the genes $C D 274$ (PD- $L 1$ ) and $P D C D 1 L G 2$ (PD-L2), which are involved in immune evasion in cancer. Wenting Huang et al. [20] maintained that there is a high frequency of clonal IG and T-cell receptor gene rearrangements in FDCS. Luisa Lorenzi et al. [21] pointed out two markers, FDCSP and SRGN, by whole transcriptome sequencing. Maria Antonella Laginestra et al. [22] indicated that the mRNA expression levels of PD-1, PD-L1 and PD-L2 are higher than other MTs comparing to FDCS. Differing from the previous study, our case is the first case using whole-gene chip

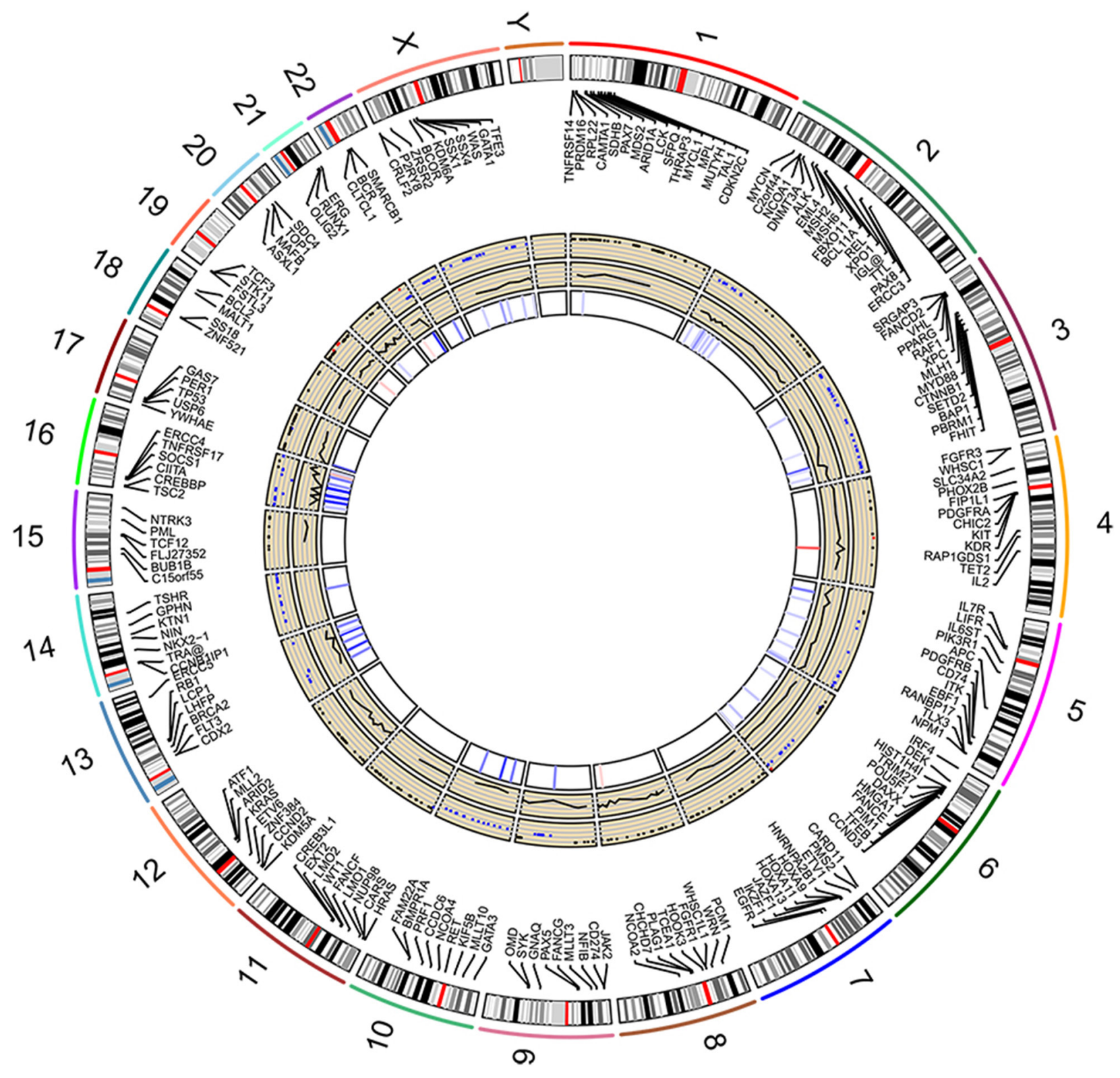

Figure 3: Copy number whole-genome profile of FDCS output from OncoScan Console. The outer ring shows the chromosome location; the next inner rings mark genes from Cancer Gene Census and indicate expression level of them; the inner most ring designates median probe level of marked genes. Red bands indicate copy number gain in corresponding region while blue bands indicate copy number loss. 
Table 1: Primary FDCS of the lung in English literature

\begin{tabular}{|c|c|c|c|c|c|c|c|c|}
\hline Case & $\begin{array}{c}\text { Age/ } \\
\text { gender }\end{array}$ & $\begin{array}{l}\text { Maximal } \\
\text { size }\end{array}$ & Site & Symptom & $\begin{array}{c}\text { Initial } \\
\text { diagnosis }\end{array}$ & $\begin{array}{l}\text { Concomitant } \\
\text { disease }\end{array}$ & Treatment & Outcome \\
\hline 1 & $33 / \mathrm{M}$ & $9.5 \mathrm{~cm}$ & left lung & $\begin{array}{l}\text { persistent dry } \\
\text { cough }\end{array}$ & FDCS & NA & $\begin{array}{c}\text { chemotherapy } \\
\text { excision }\end{array}$ & $\begin{array}{c}\text { axillary RC } \\
19 \mathrm{~ms}\end{array}$ \\
\hline 2 & $65 / \mathrm{M}$ & $4 \mathrm{~cm}$ & left upper lobe & no symptoms & FDCS & NIDDM & excision & $18 \mathrm{~ms} \mathrm{DF}$ \\
\hline 3 & $64 / F$ & $1.7 \mathrm{~cm}$ & $\begin{array}{l}\text { right lower } \\
\text { lobe }\end{array}$ & $\begin{array}{l}\text { cough and } \\
\text { shortness of } \\
\text { breath }\end{array}$ & pneumonia & asthma & excision & 2ys NS \\
\hline 4 & $49 / \mathrm{M}$ & $5 \mathrm{~cm}$ & left lower lobe & no symptoms & $\begin{array}{c}\text { primary lung } \\
\text { carcinoma }\end{array}$ & NA & $\begin{array}{c}\text { excision } \\
\text { radiotherapy } \\
\text { chemotherapy }\end{array}$ & $1 y \mathrm{DF}$ \\
\hline 5 & 26/M & $8.5 \mathrm{~cm}$ & hilar region & $\begin{array}{c}\text { chest pain and } \\
\text { cough }\end{array}$ & $\begin{array}{l}\text { Inflammatory } \\
\text { myofibroblastic } \\
\text { tumor }\end{array}$ & NA & $\begin{array}{c}\text { excision } \\
\text { radiotherapy } \\
\text { chemotherapy }\end{array}$ & 10m STD \\
\hline 6 & $51 / \mathrm{M}$ & $2.4 \mathrm{~cm}$ & $\begin{array}{l}\text { right middle } \\
\text { lobe }\end{array}$ & chronic cough & FDCS & NO & excision & NA \\
\hline 7 & $76 / \mathrm{F}$ & $3 \mathrm{~cm}$ & NA & dyspnea & $\begin{array}{l}\text { malignant } \\
\text { melanoma }\end{array}$ & NA & surgery & STD \\
\hline 8 & $20 / \mathrm{M}$ & $7 \mathrm{~cm}$ & $\begin{array}{l}\text { right perihilar } \\
\text { region }\end{array}$ & dryness & FDCS & PNP & $\begin{array}{c}\text { excision } \\
\text { chemotherapy }\end{array}$ & NA \\
\hline
\end{tabular}

NA: not available, RC: recurrence, DF: disease free STD: submitted to disease, PNP: paraneoplastic pemphigus, NIDDM: non-insulin dependent diabetes mellitus.
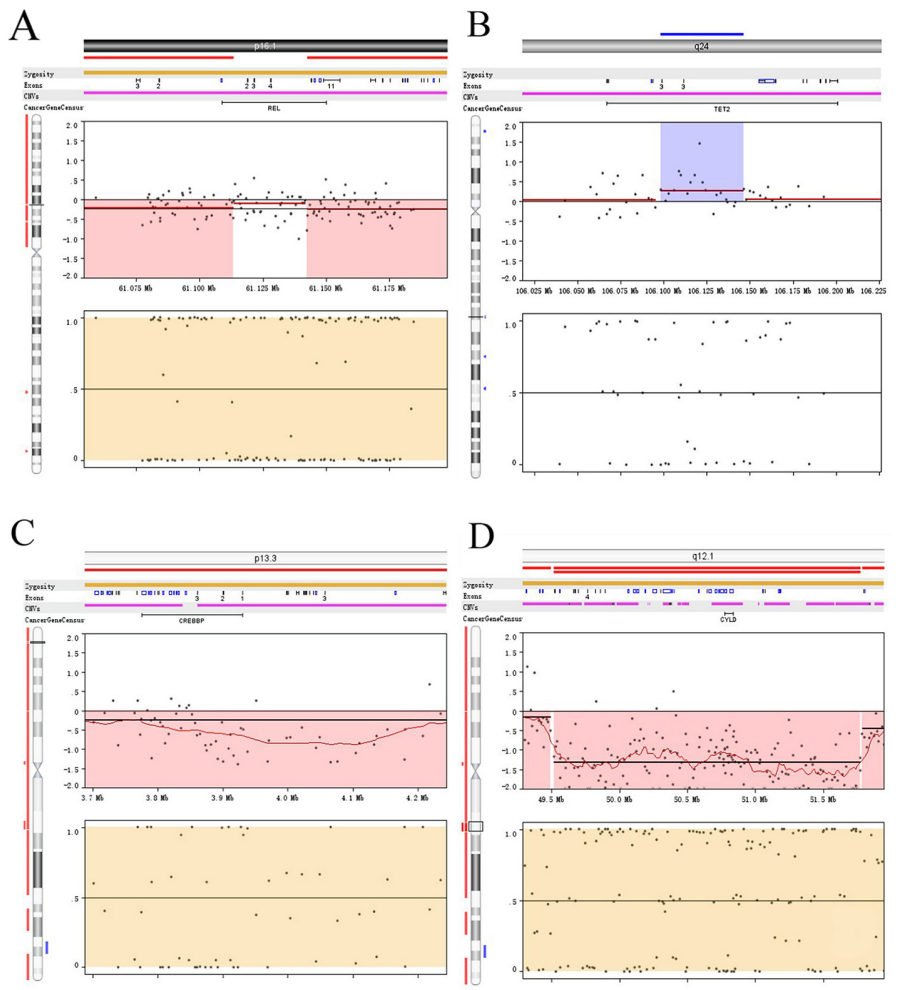

Figure 4: Copy number variants of the interested genes. (A) $R E L$ was $L O H$ while the adjacent regions were detected $\mathrm{CN}$ loss. (B) Part of TET2 was amplification while part of it was CN loss. (C) CN loss of CREBBP has more loss comparing to the adjacent part, hinting the homozygous deletion to this gene. (D) Homozygous deletion was found in CYLD. 
to study the global landscape of gene characteristics and we focused on the CNVs in this tumor. In the meantime, we dug into the involved genes and aimed to find some functional members.

REL locates at chromosome 2p13-p12. According to the segmentation analysis, $\mathrm{LOH}$ was detected in this region while $\mathrm{CN}$ loss was detected in adjacent regions, suggesting the amplification of REL. In solid tumors, amplification of genes may be related to regulate cell proliferation or drug resistance [23]. REL is the most frequently amplified gene in germinal center (GC) derived B cell lymphoma, including GC DLBCL, follicular lymphoma and classical Hodgkin disease [24] and it shows amplification in 23\% DLBC in TCGA. This gene encodes a member of the $R E L /$ nuclear factor- $\mathrm{kB}(R E L /$ $N F-k B$ ) family of transcription factors, which act on cell growth, differentiation and survival regulation, especially in hematopoietic lineages [24]. One recent study found several recurrent somatic alterations in FDCS, which involve in the negative regulation of $N F-k B$ activation [19]. Our result infers another possible mechanism of $N F-\kappa B$ activation, hinting the vital role of $R E L$ in this neoplasm. TET2 locates at chromosome 10q24. In this gene, a part of it is amplification while the adjacent parts were $\mathrm{CN}$ loss, suggesting the possibility of the loss of function. In 2009, TET2 was first discovered in myeloid malignancies, such as myelodysplastic syndrome(MDS) [25], chronic myelomonocytic leukemia(CMML) [26], acute myeloid leukemia (AML) [27], and myeloproliferative neoplasms(MPN) [28]. Then, recurrent mutation was found in subtypes of mature T/NE-cell neoplasms such as mature B-cell lymphoma, diffuse large B-cell lymphoma. Somatic TET2 mutations cause impairment of activity of the TET2 dioxygenase and the $\mathrm{CNV}$ of this gene in our case may also lead to the loss of function, resulting in the failure of $5-\mathrm{mC}$ to $5-\mathrm{hmC}$ conversion, and eventually the failure of demethylation [29]. CREBBP locates at 16p13.3. CN loss was detected in this region and part of $C R E B B P$ has more loss comparing to the adjacent genes, hinting the homozygous deletion of this gene. $C R E B B P$ is one of the most frequently mutated chromatin modifying gene in FL and DLBCL, second to $K M T 2 D$ [30]. This gene encodes the transcriptional coactivator and histone acetyltransferase CREB-binding protein. Any type of loss of function impairs histone acetylation and transcriptional regulation of $C R E B B P$ targets [31]. Loss-of-function $C R E B B P$ mutations in FL has been shown to assist evasion by down regulating MHC class II expression along with reducing $\mathrm{T}$ cell infiltration [32]. Furthermore, patients carrying $C R E B B P$ mutation tend to have high risks because of acetylation imbalance. CYLD locates at 16q12. Homozygous deletion was found in this region. CYLD was originally identified in familial cylindromatosis(Brooke-Spiegler syndrome) and was linked to pathogenesis of several tumors, such as melanoma, T-cell acute lymphoblastic leukemia, colon carcinoma and hepatocellular carcinoma [33]. CYLD is a negative regulator of $\mathrm{NF}-\kappa \mathrm{B}$ and $\mathrm{Wnt} / \beta$-catenin signaling, and loss of CYLD by deletion or mutations may sensitize cells to NF- $\kappa \mathrm{B}$-stimuli and Wnt ligands [33].

There lie some limitations in our study. The first one is from the intrinsic defect of the OncoScan FFPE Assay Kit. This kit has extremely high sensitivity and specificity in CNVs detection, but there still are a small number of SMs that could not be reliably validated [34], and chromosome balanced translocation and chromosome inversion cannot be detected. Besides, unfortunately the patient died three days after surgery which leads to the lack of treatment information about this tumor. Moreover, the only case restricts our result reproducing. Nevertheless, the significance from our case remains to mention. We found some crucial genes by bioinformatics and literature review, which have important influence on the fate of the neoplasm and can be latent therapy targets. For this rare and under-recognized tumor, it is the first time to raise the genetic testing method for diagnosis.

In summary, the impactful therapeutic intervention requires a global understanding of the genomic mutations that drive tumor occurrence and development. For this reason, the whole genetic testing combining with bioinformatics' analysis bulks large, especially for the rare neoplasm because the number of cases from one or several institutions is usually small. Only in this way can we have a perfect management for this tumor.

\section{Ethics statement}

The study was approved by the institutional review board (IRB) at the Shandong Tumor Hospital and Institute (IRB ID: 201706002).

\section{Abbreviations}

$\mathrm{FDCS}=$ follicular dendritic cell sarcoma, $\mathrm{CT}=$ computed tomographic, $\mathrm{IHC}=$ immunohistochemistry, $\mathrm{CNV}=$ copy number variations, $\mathrm{SNP}=$ single nucleotide polymorphisms, $\mathrm{LOH}=$ loss of heterozygosity, $\mathrm{FFPE}=$ formalin fixed, paraffin-embedded, MIP $=$ molecular inversion probe.

\section{Author contributions}

Liyuan Fan had full access to all of the data in the study and takes responsibility for the integrity of the data and the accuracy of the data analysis. Baosheng Li and Hongsheng Li did the study concept, design, and drafting of the manuscript. Minghao Li and Yang Zhang did the acquisition, analysis, and interpretation of genetic testing. Jianping Zhang did the immunohistochemical analysis. All authors read and approved the final manuscript. 


\section{CONFLICTS OF INTEREST} interest.

The authors declare that they have no competing

\section{FUNDING}

This study was supported in part by 81530060 from National Nature Science Foundation of China, and 2016YFC0105100 from The National Key Research and Development Plan.

\section{Consent of publication}

Informed consent for publication was obtained and is available for review by the editor.

\section{REFERENCES}

1. Tew JG, Thorbecke GJ, Steinman RM. Dendritic cells in the immune response: characteristics and recommended nomenclature (a report from the Reticuloendothelial Society Committee on Nomenclature). J Reticuloendothel Soc. 1982; 31:371-80.

2. Monda L, Warnke R, Rosai J. A primary lymph node malignancy with features suggestive of dendritic reticulum cell differentiation. A report of 4 cases. Am J Pathol. 1986; 122:562-72.

3. Vardiman JW. The world health organization (WHO) classification of tumors of the hematopoietic and lymphoid tissues: an overview with emphasis on the myeloid neoplasms. Chem Biol Interact. 2010; 184:16-20. https:// doi.org/10.1016/j.cbi.2009.10.009.

4. Fonseca R, Yamakawa M, Nakamura S, Van Heerde P, Miettinen M, Shek T, Jensen OM, Rousselet M, Tefferi A. Follicular dendritic cell sarcoma and interdigitating reticulum cell sarcoma: a review. Am J Hematol. 1998; 59:161-7.

5. Shah RN, Ozden O, Yeldandi A, Peterson L, Rao S, Laskin WB. Follicular dendritic cell tumor presenting in the lung: a case report. Hum Pathol. 2001; 32:745-9. https://doi. org/10.1053/hupa.2001.25595.

6. Kovacs RB, Sattar HA, Krausz T, Kas J, Berta M, Sapi Z. Primary follicular dendritic cell sarcoma of the lung. Histopathology. 2006; 49:431-3. https://doi. org/10.1111/j.1365-2559.2006.02486.x.

7. Denning KL, Olson PR, Maley RH Jr, Flati VR, Myers JL, Silverman JF. Primary pulmonary follicular dendritic cell neoplasm: a case report and review of the literature. Arch Pathol Lab Med. 2009; 133:643-7. https://doi. org/10.1043/1543-2165-133.4.643.

8. Hollingsworth J, Cooper WA, Nicoll KD, Wills EJ, Thiruvilangam V, Lee CS, Scolyer RA. Follicular dendritic cell sarcoma of the lung: a report of two cases highlighting its pathological features and diagnostic pitfalls. Pathology. 2011; 43:67-70. https://doi.org/10.1097/ PAT.0b013e3283419e2a.

9. Kim H, Park CM, Jeon YK, Yoo LR, Song SW, Goo JM, Lee HJ. Computed tomography and 18F-fluoro-2deoxyglucose positron emission tomography findings of primary pulmonary follicular dendritic cell sarcoma: case report and a literature review. J Thorac Imaging. 2012; 27:W94-6. https://doi.org/10.1097/RTI.0b013e318220309f.

10. Wang RF, Han W, Qi L, Shan LH, Wang ZC, Wang LF. Extranodal follicular dendritic cell sarcoma: a clinicopathological report of four cases and a literature review. Oncol Lett. 2015; 9:391-8. https://doi.org/10.3892/ ol.2014.2681.

11. Garza-Chapa JI, Ocampo-Garza J, Vazquez-Herrera NE, Miranda-Maldonado IC, Rendon-Ramirez E, GonzalezChavez JM, Garcia-Garcia SC, Montero-Cantu CA, Ocampo-Candiani J. Paraneoplastic pemphigus associated with primary pulmonar follicular dendritic cell sarcoma showing good response to treatment. J Eur Acad Dermatol Venereol. 2016; 30:465-7. https://doi.org/10.1111/ jdv.12842.

12. Bhattacharya D, Datta S, Das A, Halder KC, Chattopadhyay S. Primary pulmonary synovial sarcoma: a case report and review of literature. Int J Appl Basic Med Res. 2016; 6:635. https://doi.org/10.4103/2229-516x.174019.

13. Schwarz RE, Chu P, Arber DA. Extranodal follicular dendritic cell tumor of the abdominal wall. J Clin Oncol. 1999; 17:2290-2.

14. Saygin C, Uzunaslan D, Ozguroglu M, Senocak M, Tuzuner N. Dendritic cell sarcoma: a pooled analysis including 462 cases with presentation of our case series. Crit Rev Oncol Hematol. 2013; 88:253-71.

15. Perry AM, Nelson M, Sanger WG, Bridge JA, Greiner TC. Cytogenetic abnormalities in follicular dendritic cell sarcoma: report of two cases and literature review. In Vivo. 2013; 27:211-4.

16. Starr JS, Attia S, Joseph RW, Menke D, Casler J, Smallridge RC. Follicular dendritic cell sarcoma presenting as a thyroid mass. J Clin Oncol. 2015; 33:e74-6. https://doi. org/10.1200/jco.2013.49.3213.

17. Go H, Jeon YK, Huh J, Choi SJ, Choi YD, Cha HJ, Kim HJ, Park G, Min S, Kim JE. Frequent detection of BRAF(V600E) mutations in histiocytic and dendritic cell neoplasms. Histopathology. 2014; 65:261-72. https://doi. org/10.1111/his.12416.

18. Hartmann S, Doring C, Agostinelli C, Portscher-Kim SJ, Lonardi S, Lorenzi L, Fuligni F, Martinez D, Mehta J, Borges A, Hackstein H, Kippenberger S, Piccaluga PP, et al. miRNA expression profiling divides follicular dendritic cell sarcomas into two groups, related to fibroblasts and myopericytomas or Castleman's disease. Eur J Cancer. 2016; 64:159-66.

19. Griffin GK, Sholl LM, Lindeman NI, Fletcher CD, Hornick JL. Targeted genomic sequencing of follicular dendritic 
cell sarcoma reveals recurrent alterations in NF-kappaB regulatory genes. Mod Pathol. 2016; 29:67-74. https://doi. org/10.1038/modpathol.2015.130.

20. Huang W, Qiu T, Zeng L, Zheng B, Ying J, Feng X. High frequency of clonal IG and T-cell receptor gene rearrangements in histiocytic and dendritic cell neoplasms. Oncotarget. 2016; 7:78355-62. https://doi.org/10.18632/ oncotarget. 13058 .

21. Lorenzi L, Doring C, Rausch T, Benes V, Lonardi S, Bugatti M, Campo E, Cabecadas J, Simonitsch-Klupp I, Borges A, Mehta J, Agostinelli C, Pileri SA, et al. Identification of novel follicular dendritic cell sarcoma markers, FDCSP and SRGN, by whole transcriptome sequencing. Oncotarget. 2017; 8:16463-72. https://doi.org/10.18632/ oncotarget. 14864.

22. Laginestra MA, Tripodo C, Agostinelli C, Motta G, Hartmann S, Doring C, Rossi M, Melle F, Sapienza MR, Tabanelli V, Pileri A, Fuligni F, Gazzola A, et al. Distinctive histogenesis and immunological microenvironment based on transcriptional profiles of follicular dendritic cell sarcomas. Mol Cancer Res. 2017; 15:541-52.

23. Bagci O, Kurtgoz S. Amplification of cellular oncogenes in solid tumors. N Am J Med Sci. 2015; 7:341-6.

24. Houldsworth J, Olshen AB, Cattoretti G, Donnelly GB, Teruya-Feldstein J, Qin J, Palanisamy N, Shen Y, Dyomina K, Petlakh M, Pan Q, Zelenetz AD, Dalla-Favera R, et al. Relationship between REL amplification, REL function, and clinical and biologic features in diffuse large B-cell lymphomas. Blood. 2004; 103:1862-8.

25. Langemeijer SM, Kuiper RP, Berends M, Knops R, Aslanyan MG, Massop M, Stevens-Linders E, van Hoogen P, van Kessel AG, Raymakers RA, Kamping EJ, Verhoef GE, Verburgh E, et al. Acquired mutations in TET2 are common in myelodysplastic syndromes. Nat Genet. 2009; 41:838-42.

26. Tefferi A, Pardanani A, Lim KH, Abdel-Wahab O, Lasho TL, Patel J, Gangat N, Finke CM, Schwager S, Mullally A, Li CY, Hanson CA, Mesa R, et al. TET2 mutations and their clinical correlates in polycythemia vera, essential thrombocythemia and myelofibrosis. Leukemia. 2009; 23:905-11.

27. Delhommeau F, Dupont S, Della Valle V, James C, Trannoy S, Masse A, Kosmider O, Le Couedic JP, Robert F, Alberdi A, Lecluse Y, Plo I, Dreyfus FJ, et al. Mutation in TET2 in myeloid cancers. N Engl J Med. 2009; 360:2289-301.

28. Jankowska AM, Szpurka H, Tiu RV, Makishima H, Afable M, Huh J, O'Keefe CL, Ganetzky R, McDevitt MA, Maciejewski JP. Loss of heterozygosity 4q24 and TET2 mutations associated with myelodysplastic/ myeloproliferative neoplasms. Blood. 2009; 113:6403-10.

29. Chiba S. Dysregulation of TET2 in hematologic malignancies. Int J Hematol. 2017; 105:17-22.

30. Garcia-Ramirez I, Tadros S, Gonzalez-Herrero I, MartinLorenzo A, Rodriguez-Hernandez G, Moore D, Ruiz-Roca L, Blanco O, Alonso-Lopez D, Rivas JL, Hartert K, Duval $\mathrm{R}$, Klinkebiel D, et al. Crebbp loss cooperates with $\mathrm{Bcl} 2$ overexpression to promote lymphoma in mice. Blood. 2017; 129:2645-56.

31. Mullighan CG, Zhang J, Kasper LH, Lerach S, PayneTurner D, Phillips LA, Heatley SL, Holmfeldt L, CollinsUnderwood JR, Ma J, Buetow KH, Pui CH, Baker SD, et al. CREBBP mutations in relapsed acute lymphoblastic leukaemia. Nature. 2011; 471:235-9.

32. Korfi K, Ali S, Heward JA, Fitzgibbon J. Follicular lymphoma, a B cell malignancy addicted to epigenetic mutations. Epigenetics. 2017; 12:370-7.

33. van Andel H, Kocemba KA, de Haan-Kramer A, Mellink $\mathrm{CH}$, Piwowar M, Broijl A, van Duin M, Sonneveld P, Maurice MM, Kersten MJ, Spaargaren M, Pals ST. Loss of CYLD expression unleashes Wnt signaling in multiple myeloma and is associated with aggressive disease. Oncogene. 2017; 36:2105-15.

34. Wood HM, Foster JM, Taylor M, Tinkler-Hundal E, Togneri FS, Wojtowicz P, Oumie A, Spink KG, Brew F, Quirke P. Comparing mutation calls in fixed tumour samples between the affymetrix $\operatorname{OncoScan}(\mathrm{R})$ array and PCR based next-generation sequencing. BMC Med Genomics. 2017; 10:017-0254. 